\title{
Analysis of enzymically digested food proteins by Sephadex-gel filtration
}

\author{
By J. E. FORD AND D. N. SALTER \\ National Institute for Research in Dairying, Shinfield, Reading
}

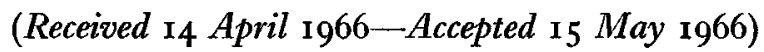

\begin{abstract}
I. Portions of a preparation of freeze-dried cod fillet were subjected to different conditions of heat treatment and were then digested in vitro with pronase (an enzyme preparation from Streptomyces griseus), or successively with pepsin, pancreatin and erepsin, or with pepsin and papain. 'The digestions were conducted under 'static' conditions in flasks, and also in Sephadex gel $\mathrm{G}$ io in such a manner that the reaction products were continuously removed from the site of action of the digesting enzymes. The different digests were then passed in turn through a calibrated column of Sephadex gel G25 and each was resolved into three fractions containing 'soluble protein', 'peptide' and 'free amino acids'. The distribution of several amino acids in these different fractions was determined and the results were assessed in relation to the availabilities of these amino acids in the original test proteins as measured in microbiological and chemical tests and, in some instances, in growth tests with rats. 2. The different enzyme systems gave broadly similar results. With increasing severity of heating, the 'free amino acids' component in the digests became increasingly deficient in several amino acids relative to their content in the original unheated meal, and notably in lysine and the sulphur-containing amino acids. This evidence for a marked differential effect of heating in retarding the enzymic release in vitro of several amino acids was consistent with the results of feeding tests with rats, and of microbiological and chemical assays, which showed corresponding differences in the proportions of lysine, methionine and isoleucine made unavailable by the heat treatment. In severely heated meal more of the lysine, methionine and isoleucine was released by enzymes in vitro than was biologically available to the rat. With increasing severity of heat treatment, the biological availabilities of these amino acids for the rat fell more sharply than did the digestibility of the nitrogen, indicating that amino acids absorbed from the heated meals were relatively poorly retained.
\end{abstract}

Although heat processing may cause little or no change in the amino acid composition of a food protein, it may profoundly influence the course of its digestion. It may cause marked changes in the relative susceptibilities of different amino acids to enzymic liberation and so, notwithstanding the evidence of the total amino acid analysis, the biologically effective amino acid compositions of the heated and the unheated protein may be widely different.

Melnick, Oser \& Weiss (1946) argued that time and concentration relationships determine the efficiency with which the amino acids are utilized after enzymic release and postulated that, for optimum utilization of a food protein, all the essential amino acids must not only be made available for absorption but must also be liberated during digestion in vivo at rates permitting mutual supplementation. Ford (r965) demonstrated with preparations of cod muscle protein the effects of heat processing in retarding the enzymic release in vitro of several amino acids, but stressed the difficulties in interpreting the nutritional significance of his results, and those of other workers using similar in vitro digestion procedures. He pointed out that the findings might reflect more closely the specificities of the enzymes chosen for bringing about the hydrolysis, and the different abilities of different test micro-organisms to hydrolyse 
the soluble peptides released during the digestion, rather than the relative susceptibilities of the different amino acids to enzymic release. Some questions concerning the unequal rates of release of different amino acids from damaged proteins must finally be decided, with animals, by direct experiments designed to allow comparison of the rate and efficiency of uptake of the different amino acids from the meals of test protein. However, the technical difficulties in this approach are considerable and complicate the interpretation of the results. There is a problem that the endogenous protein is digested and reabsorbed, and 'buffers' changes in the pattern of amino acids passed to the portal blood. The mucosal barrier may similarly exercise a regulatory effect during the active +ronsport of amino acids from the gut. Nasset (1956) indeed concluded that 'the digestive tract imposes more or less of a set pattern on the amino acid mixture available for absorption after the ingestion of a test meal'. Such a homoeostatic mechanism could clearly not operate during prolonged ingestion of a diet providing a limiting amount of any essential nutrient, but might need to be taken into account during the planning of experiments of shorter duration. Because of these and other difficulties of the in vivo approach, we have thought it worth while to extend a preliminary study (Ford, 1965) on the effects of heating on the in vitro digestibility of cod muscle protein, to provide results for direct comparison with those from a parallel study with rats (S. Buraczewski \& J. W. G. Porter, unpublished).

Digestion in vitro generally involves the accumulation of products which in vivo are rapidly absorbed and which may progressively inhibit the digestive reactions. The pattern of free amino acids in the digest could be modified by the different susceptibilities of different peptidases to product inhibition. Also, in the presence of an accumulation of their products, trypsin and chymotrypsin may function increasingly as trans-peptidases. Mauron, Mottu, Bujard \& Egli (1955) recognized these problems and employed an in vitro digestion procedure in which the test protein was simultaneously digested and dialysed, first with pepsin and then with pancreatin. In the study now presented we have similarly attempted the continuous removal of reaction products from the system by causing the enzyme-substrate mixture to pass as a narrow band down a heated column of Sephadex gel Gro. Another considerable problem is to reproduce in vitro the complex multi-enzyme systems that operate in the animal's gut, and to provide a representative quota of the peptidases that are mainly responsible for converting small peptides into free amino acids. In our study we have compared three different enzyme systems. In one, the test proteins were digested with pepsin and were then digested successively with pancreatin and erepsin on the Sephadex column, or under static conditions in a flask. In another experiment the test proteins were digested with pronase, or alternatively with pepsin followed by pronase. Pronase is a proteolytic enzyme of Streptomyces griseus and has an unusually broad substrate specificity. Nomoto, Narahashi \& Murakami (1960) found it capable of hydrolysing many peptides, amides and esters, including most of the specific substrates of pepsin, trypsin, chymotrypsin, papain, cathepsin $\mathrm{C}$, carboxypeptidase, leucine aminopeptidase, aminotripeptidase and several other proteolytic enzymes. For a third experiment the test proteins were digested in a flask successively with pepsin and with papain. 
All these different digests were passed in turn through a calibrated column of Sephadex gel G25 (cf. Ford, 1965) and were each resolved into three fractions containing (I) 'soluble protein', (2) 'peptide' and (3) 'free amino acids'. Besides these three fractions there was in each digest a residue of undigested material which was retained for analysis. All the fractions and residues, and the original test proteins, were assayed microbiologically for lysine, methionine, arginine, histidine, valine, leucine, isoleucine, threonine and glutamic acid, and some were assayed also for cystine, tyrosine and aspartic acid. In addition, the availabilities in the original test proteins of several of these amino acids were determined by microbiological assay with Streptococcus zymogenes.

\section{EXPERIMENTAL}

\section{Materials}

Test proteins. The test proteins were prepared by our colleague, Dr J. W. G. Porter, as follows: a freeze-dried fish meal was made from fillets of cod (Gadus morrhua) as described by Ford (1965). Portions of the meal weighing about $25^{\circ} \mathrm{g}$ were spread in layers about $\mathrm{x} .5 \mathrm{~cm}$ deep in each of two stainless-steel trays. The trays were heated in an air oven for $18 \mathrm{~h}$, one at $135^{\circ}$ and the other at $145^{\circ}$. After being heated at $135^{\circ}$ the meal had changed from creamy-white to primrose-yellow in colour. After heating at $145^{\circ}$ the colour had become a deep orange-yellow. All the preparations were stored at $2^{\circ}$ in tightly stoppered Polythene bottles.

Enzymes. The following commercial enzyme preparations were used: crystalline pepsin from pig's stomach mucosa; crystalline trypsin from bovine pancreas; pancreatin, $3 \times$ USP grade, from pig's pancreas; erepsin from pig's intestine (all purchased from Koch-Light Laboratories Ltd, Colnbrook); papain, partly purified grade (Schering, Berlin); pronase, purified, B grade (Calbiochem, Los Angeles, USA).

\section{Preparation of digests}

Samples of the freeze-dried cod fillet, and of the two heated preparations, were digested in vitro in flasks, with frequent stirring of the reaction mixture, and also in Sephadex gel, as described below.

\section{Digestion in flasks}

Pepsin, pancreatin and erepsin. The $\mathrm{N}$ content of the test proteins was determined by macro-Kjeldahl analysis. Samples of each, containing I $g$ N, were weighed into glassstoppered conical flasks of $500 \mathrm{ml}$ capacity, to which were added $150 \mathrm{ml} 0.05 \mathrm{~N}-\mathrm{HCl}$. The contents of the flasks were allowed to stand for $30 \mathrm{~min}$ and their $\mathrm{pH}$ values were adjusted to $\mathrm{I} \cdot 8$ by addition of $\mathrm{N}-\mathrm{HCl}$. To each flask were added $100 \mathrm{mg}$ crystalline pepsin. The flasks were placed in a water bath at $37^{\circ}$ and their contents stirred gently for $3^{\circ} \mathrm{min}$. The $\mathrm{pH}$ values were again adjusted to $\mathrm{r} \cdot 8$ and incubation at $37^{\circ}$ was continued for a further $23^{\frac{1}{2}} \mathrm{~h}$, with frequent stirring during the first $8 \mathrm{~h}$ of incubation. After digestion for $24 \mathrm{~h}$ with pepsin, $\mathrm{N}-\mathrm{NaOH}$, to bring the $\mathrm{pH}$ values of the digests to about 7 , and $\mathrm{I}_{5} \mathrm{~g} \mathrm{NaHCO}_{3}$ were added. The $\mathrm{pH}$ values were now adjusted to $8 \cdot 2$, and $5 \circ \mathrm{mg}$ crystalline trypsin and $100 \mathrm{mg}$ pancreatin were added to each digest. 
After stirring for $3 \circ \mathrm{min}$ at $37^{\circ}, 5 \mathrm{ml}$ of sulphur-free toluene were added. The flasks were stoppered tightly and incubated for a further period of $24 \mathrm{~h}$, with frequent swirling of the contents during the first $8 \mathrm{~h}$ of incubation. To each were added $7.5 \mathrm{ml}$ of a solution prepared by grinding $2 \mathrm{~g}$ erepsin with $40 \mathrm{ml} 0.02 \mathrm{M}-\mathrm{phosphate}$ of $\mathrm{pH} 7 \cdot 6$ for Io min at room temperature, centrifuging and decanting through a plug of cottonwool in a filter funnel. Incubation was now continued for a further period of $24 \mathrm{~h}$, again with frequent swirling of the contents of the flasks during the first $8 \mathrm{~h}$. The digests were transferred to $250 \mathrm{ml}$ centrifuge bottles with an additional $20 \mathrm{ml}$ water used for rinsing the flasks, and centrifuged for $30 \mathrm{~min}$ at $185^{\circ} \mathrm{g}$. The supernatant fluids were decanted. The residues were suspended in $50 \mathrm{ml}$ water and centrifuged again. The washings were decanted and combined with the digests, and the whole was evaporated under reduced pressure in a rotary evaporator to about $150 \mathrm{ml}$. The digests were now free from toluene. Their $\mathrm{N}$ content was determined by microKjeldhal analysis, and the volume of water needed to bring its $\mathrm{N}$ content to $5 \mathrm{mg} / \mathrm{ml}$ was added to each digest. The residues were dried at room temperature in a vacuum desiccator and weighed, and their $\mathrm{N}$ contents determined.

Pepsin and papain. Samples of the test proteins containing I $\mathrm{g} \mathrm{N}$ were digested with pepsin as described above. To each digest were then added $0.5 \mathrm{~g}$ trisodium citrate and enough $\mathrm{N}-\mathrm{NaOH}$ to bring the $\mathrm{pH}$ value to 6.5 . Next were added $25 \mathrm{mg} \mathrm{NaCN}$, and the $\mathrm{pH}$ values were adjusted to 7.0 ; 100 $\mathrm{mg}$ of papain were added, and $5 \mathrm{ml}$ of sulphur-free toluene. The flasks were stoppered tightly and incubated for $24 \mathrm{~h}$ at $37^{\circ}$, with frequent swirling of the contents during the first $8 \mathrm{~h}$. The digests were now clarified by centrifuging and adjusted to contain $5 \mathrm{mg} \mathrm{N} / \mathrm{ml}$; the washed residues were dried and weighed and their $\mathrm{N}$ content was determined. The procedure subsequently followed was as described above for the pepsin, pancreatin and erepsin digests.

Pronase. Samples of the test proteins containing $\mathrm{I} g \mathrm{~N}$ were weighed into glassstoppered conical flasks of $500 \mathrm{ml}$ capacity, to which were added $200 \mathrm{ml} 0.2 \mathrm{M}$ solution of sodium $\beta$-glycerophosphate of $\mathrm{pH} 8 \cdot 0$. To each were added Io $\mathrm{ml}$ of a $\mathrm{I} \cdot 25 \%(\mathrm{w} / \mathrm{v})$ solution of pronase in the glycerophosphate solution. The flasks were incubated for $4 \mathrm{~h}$ in a water bath at $56^{\circ}$, with frequent stirring. Ethanol $(8 \mathrm{ml})$ was then added slowly to each flask, to provide a concentration in the digestion mixture of about $4 \%$. At this concentration ethanol prevents the growth of bacteria during the course of the incubation but has no effect on the activity of the proteinase (Nomoto et al. r 960$)$. The flasks were stoppered tightly and returned to the water bath for a further $17 \mathrm{~h}$. The digests were centrifuged and adjusted to contain $5 \mathrm{mg} \mathrm{N} / \mathrm{ml}$, and the residues weighed and their $\mathrm{N}$ contents measured, as described above.

\section{Digestion in Sephadex gel}

Fractionation in Sephadex gel offers a simple means of separating completely solutes of high and low molecular weight. If we pass a solution containing proteins, peptides and amino acids down a column of Sephadex gel G 10 we find that the proteins, and peptides of molecular weight greater than about 700 , do not enter the gel particles and percolate through the column in the liquid phase outside the particles; they are therefore eluted first, in the so-called void volume. Peptides of $M c .700$ and smaller, 
and free amino acids, penetrate the gel particles and are retarded in their passage down the column, and emerge from the column in approximate order of diminishing molecular size. In the present experiments the test proteins were first digested for $24 \mathrm{~h}$ with pepsin, as described on p. 845 . Portions of these digests were then passed at a controlled slow rate down a warmed column of Sephadex gel G io, together with extracts of pancreatin and erepsin, or with pronase. Free amino acids and smaller peptides were in this manner continuously removed from the site of the enzymic reaction as they were released.

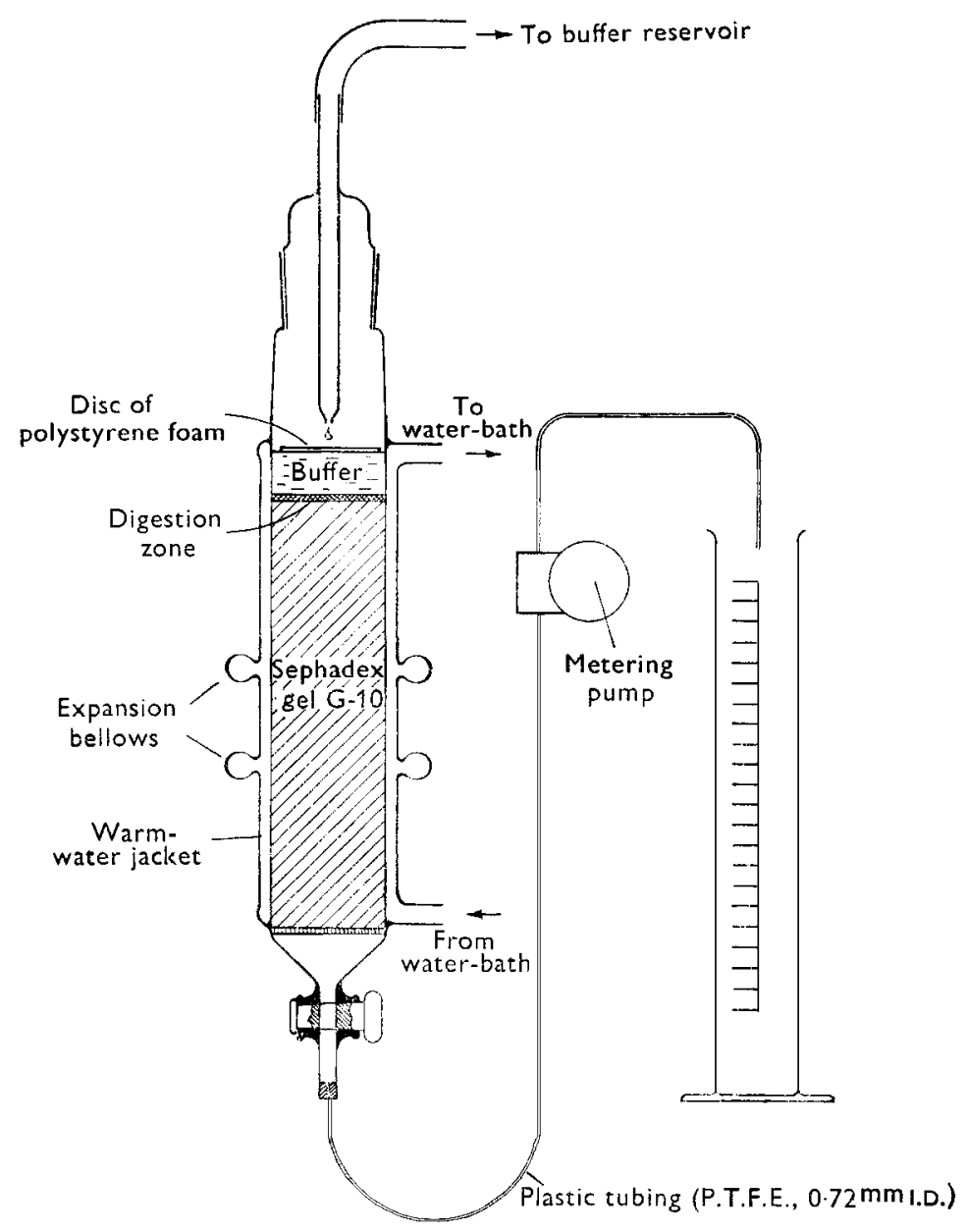

Fig. I. Digestion apparatus.

Preparation of gel column. The construction of the digestion apparatus is shown in Fig. I. Sephadex-gel filtration medium was used, type G io, lot number To 7929 , particle size 40-1 $20 \mu \mathrm{m}$ (Pharmacia, Uppsala, Sweden). Dry gel (400 g) was suspended in about $2000 \mathrm{ml} 0.02 \mathrm{M}$-sodium phosphate solution of $\mathrm{pH} 7.6$ and allowed to stand for $24 \mathrm{~h}$. The gel bed, of diameter $7 \mathrm{~cm}$ and settled height $27 \mathrm{~cm}$, was then prepared by the procedure described by Andrews (1964). Buffers employed for eluting the 
column were boiled immediately before use to expel dissolved gases, and filtered to remove any slight precipitate of phosphate, and were then transferred to a 51 . aspirator bottle fitted with a Marriotte constant pressure tube. The column outlet was connected by a length of plastic capillary tubing to a metering pump and thence to a $500 \mathrm{ml}$ measuring cylinder. The gel and the overlying buffer were maintained at $45^{\circ}$ by a water jacket through which water was pumped from a thermostatically controlled bath.

The void volume of the column was determined as $300 \mathrm{ml}$. All the amino acids excepting tyrosine and tryptophan emerged from the column in the fraction $340-$ $520 \mathrm{ml}$. Tyrosine appeared in the fraction 560-680 and tryptophan in 1080-1380 ml.

Digestion with extracts of pancreatin with added trypsin, and erepsin. Pancreatin (100 mg) was gently ground in a homogenizer tube (Ford, I964) with Io $\mathrm{ml}$ of I \% $(\mathrm{w} / \mathrm{v})$ sodium bicarbonate solution at about $20^{\circ}$. The homogenate was centrifuged for Io min at $2000 \mathrm{~g}$, and the supernatant liquid decanted.

An extract of erepsin was prepared in the same manner. Buffer solution ( 51 .) was prepared containing, per 1.: $\mathrm{NaH}_{2} \mathrm{PO}_{4} 0.6 \mathrm{~g}, \mathrm{~K}_{2} \mathrm{HPO}_{4} \mathrm{I} \cdot 4 \mathrm{~g}$, solution of mineral salts (cf. Ford, I 962) $4 \mathrm{ml}$, and enough $\mathrm{N}-\mathrm{H}_{3} \mathrm{PO}_{4}$ to bring the $\mathrm{pH}$ value to $8 \cdot 0-8 \cdot \mathrm{I}$.

To ro $\mathrm{ml}$ of pepsin digest of the test fish meal, containing $5 \mathrm{mg} \mathrm{N} / \mathrm{ml}$, were added $2 \mathrm{ml}$ extract of pancreatin and $10 \mathrm{mg}$ trypsin. After time had been allowed for the trypsin to dissolve, the mixture was transferred to the top of the Sephadex column and allowed to enter the gel bed. Two $\mathrm{ml}$ of the extract of erepsin were then taken, diluted to ro $\mathrm{ml}$ with buffer solution and also applied to the column and allowed to enter the gel bed. About $100 \mathrm{ml}$ buffer were added to the column, which was then connected to the buffer reservoir and to the metering pump, which was set to deliver $60 \mathrm{ml} / \mathrm{h}$. Over a period of $4 \frac{1}{2} \mathrm{~h} 270 \mathrm{ml}$ effluent were collected and discarded. The metering pump was then disconnected and a further $520 \mathrm{ml}$ effluent collected in a measuring cylinder placed below the column outlet; this took about $20 \mathrm{~min}$. This second collection, containing undigested protein and peptide, and all the amino acids except tryptophan, was evaporated under reduced pressure to Io $\mathrm{ml}$, transferred to a centrifuge tube and allowed to stand overnight in a refrigerator. A precipitate appeared which was centrifuged down. The supernatant liquid was decanted, and the precipitate resuspended in $4 \mathrm{ml}$ water and centrifuged again. The washings and the original concentrate were combined and the whole was diluted with water to $15 \mathrm{ml}$. The residue was hydrolysed with $6 \mathrm{~N}$-hydrochloric acid and its content of $\alpha-\mathrm{NH}_{2}$ measured by reaction with ninhydrin.

The losses of $\alpha-\mathrm{NH}_{2}$ in the residues ranged between 0.70 and $0.98 \mathrm{mg}$ leucineequivalent. This amount, negligible in relation to the roughly $500 \mathrm{mg}$ 'leucine equivalent' recovered from the Sephadex column, was ignored in further calculations.

Digestion with pronase. Pronase $(20 \mathrm{mg}$ ) was dissolved in $10 \mathrm{ml}$ pepsin digest of fish meal, and the solution transferred to the column of Sephadex G io and allowed to enter the gel bed. To the column were added about $100 \mathrm{ml}$ of buffer solution containing, per 1.: $\mathrm{NaH}_{2} \mathrm{PO}_{4} 0.6 \mathrm{~g}, \mathrm{~K}_{2} \mathrm{HPO}_{4} \mathrm{I} \cdot 4 \mathrm{~g}$, solution of mineral salts (cf. Ford, $\mathrm{r}_{962}$ ) $4 \mathrm{ml}$, enough $\mathrm{N}-\mathrm{H}_{3} \mathrm{PO}_{4}$ to bring the $\mathrm{pH}$ value to $7 \cdot 4$, and ethanol $50 \mathrm{ml}$. The column was connected to the buffer reservoir and to the metering pump, which was set to 
deliver $16 \mathrm{ml} / \mathrm{h}$. Over a period of $\mathrm{I} 7 \mathrm{~h} 270 \mathrm{ml}$ of effluent were collected. The metering pump was then disconnected and a further $520 \mathrm{ml}$ effluent were collected and concentrated to $I 5 \mathrm{ml}$ as described above for the pancreatin-erepsin digests.

Solution of pronase in the pepsin digests caused a flocculent precipitate to appear in them. This quickly redissolved except in the digest of the meal heated for $18 \mathrm{~h}$ at $145^{\circ}$, which could not therefore be applied to the gel column and was excluded from the experiment.

\section{Fractionation of enzymic digests on Sephadex gel $G 25$}

We had now prepared fourteen digests, representing the three test proteins digested in vitro with three different enzyme systems, under static conditions or under dynamic conditions in Sephadex gel G Io. A portion of each digest was now passed through a calibrated column of Sephadex gel G25 and in this manner divided arbitrarily into three fractions containing preponderantly: (I) undigested protein, and peptides of $M$ greater than about 5000 ; (2) peptides of $M$ between 5000 and about 250, and (3) free amino acids (Ford, I965). There was some overlapping of these different categories; thus the 'free amino acid' fraction contained all of the amino acids in the digests, but it also contained a proportion of small peptides-especially of peptides containing the aromatic amino acids. The fractions were reduced in volume to $20 \mathrm{ml}$ by evaporation under reduced pressure in a rotary evaporator, diluted with $5 \mathrm{ml} \mathrm{I0.5} \mathrm{N-HCl,} \mathrm{sealed}$ in ampoules and heated in steam at $12 \mathrm{I}^{\circ}$ for $\mathrm{I} 8 \mathrm{~h}$. The hydrolysates were neutralized with $4 \mathrm{~N}-\mathrm{NaOH}$ and diluted with water to $50 \mathrm{ml}$. A sample of each was then taken and assayed for its content of $\alpha$-amino $\mathrm{N}$, by reaction with the modified ninhydrin reagent of Moore \& Stein (1954). A standard reponse curve was prepared with known graded concentrations of leucine and the amounts of $\alpha-\mathrm{NH}_{2}$ in the hydrolysates were calculated in terms of leucine equivalent by reference to this standard curve.

\section{Measurement of amino acids}

The hydrolysed fractions, and hydrolysates of the corresponding test proteins and undigested residues, were assayed for methionine, valine, leucine, isoleucine, arginine, histidine, lysine, tyrosine, threonine, cystine, glutamic acid and aspartic acid. In addition, several of the enzymic digests were assayed, before being fractionated on Sephadex-gel G 25, for their content of total and available methionine, valine, leucine, isoleucine, arginine, histidine and lysine, as described by Ford (1962, 1964, 1965), but with the following refinements in procedure. Instead of employing individual amino acid standards in the different assays a composite standard was used which contained (per $\mathrm{ml}$ ): $5 \mu \mathrm{g}$ L-tryptophan, $20 \mu \mathrm{g}$ L-histidine (as the hydrochloride, monohydrate) and L-methionine, $30 \mu \mathrm{g} \mathrm{L}$-valine, $40 \mu \mathrm{g}$ L-leucine, $\mathrm{L}$-isoleucine, $\mathrm{L}$-threonine, $\mathrm{L}$-serine, and L-lysine and L-arginine (as the hydrochlorides), and $100 \mu \mathrm{g}$ L-glutamic acid (as the sodium salt). The standard was prepared by dilution of a stock aqueous solution made up at twenty times the final strength. The content of adenine, guanine, uracil and xanthine in the basal medium was doubled, as recommended by Kennedy (1965). These modifications gave a useful extension of the range of the assays by improving the parallelism of the responses to standard and test extracts at the higher dosage levels. 
Threonine was assayed with Streptococcus durans by a method similar to that referred to above for the assay with Strep. zymogenes of several other amino acids. Glutamic acid was assayed with Lactobacillus plantarum, and tyrosine, cystine and aspartic acid with Pediococcus cerevisiae P6o (Leuconostoc mesenteroides P6o) as described by Barton-Wright ( 1963$)$.

To assay cystine microbiologically the test protein must first be hydrolysed with acid, and this may involve some considerable loss of cystine. To check this, duplicate preparations were made of several of the G 25 column fractions, and their cystine content was measured as cysteic acid by the method of Moore (1963).

\section{Biological and chemical tests}

We are grateful to our colleagues, Dr Kathleen M. Henry and Dr J. W. G. Porter, for kindly allowing us to quote unpublished results of rat growth assays for available lysine, methionine, isoleucine, and tryptophan, and of a chemical test for available lysine, in the three test fish meals.

\section{RESULTS AND DISCUSSION}

Table I shows the content of biologically available lysine, methionine and isoleucine in the test proteins, measured in growth tests with rats, and the true digestibility of the N. It shows also the 'available' content of these same amino acids as indicated in microbiological and chemical tests. Heating reduced the biological availability of all three amino acids, but apparently more so that of lysine than of methionine and isoleucine. Thus, in the meal heated for $18 \mathrm{~h}$ at $135^{\circ}$, the availability of methionine and isoleucine had fallen by about $20 \%$, and that of lysine by about $60 \%$. The relatively greater loss of lysine was confirmed in the results of the chemical and microbiological tests.

Table 2 shows the amounts of methionine, valine, leucine, isoleucine, arginine, histidine and lysine in these meals that were available to Strep. zymogenes or Strep. durans after hydrolysis by different enzymic or chemical procedures. Analysis of the test proteins after hydrolysis with $4 \mathrm{~N}-\mathrm{HCl}$ showed that there was little change with heating in the content of these amino acids, except that the content of lysine fell-by $24 \%$ in the more severely heated meal. The apparent small loss of methionine was found in several independent analyses, all of which showed the content in the more severely heated meal to be about $10 \%$ smaller than that in the unheated meal.

Comparison of these 'total' values with those found for the enzymic hydrolysates showed that all of the methionine and isoleucine, and about $90 \%$ of the valine, leucine, arginine and histidine, in the enzymic digests of the unheated meal, were available to Strep. zymogenes-which is itself strongly proteolytic and largely capable of digesting proteins of good quality without the aid of foreign proteinases (Ford, 1960). About $90 \%$ of the lysine in the enzymic digests was similarly available to Strep. durans which, like Strep. zymogenes, is well endowed with peptidases.

In the heated meals the availability of these seven amino acids-and especially that of lysine-was reduced. The three different enzymic pretreatments gave broadly similar results, and all showed the available lysine in the more severely heated meal 
Vol. 20

3

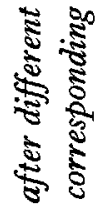

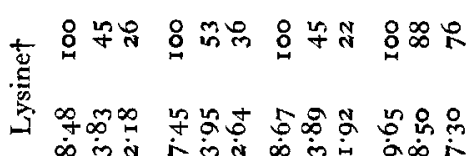

ड़

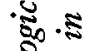

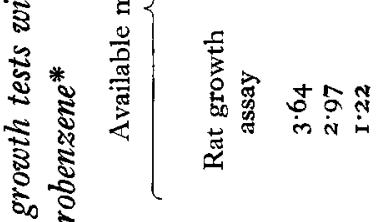

ำ ำ

(

ชั

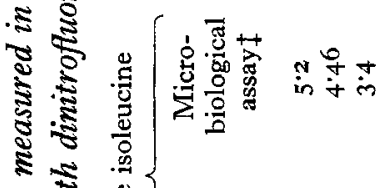

है के

s.

के

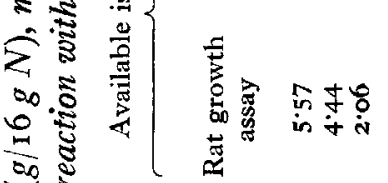

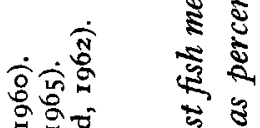

के

胥

¿ ¿

है

ฐ

运密

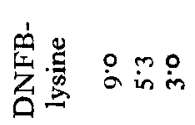

ชึ

క气

ํำ

范

प्र

氙造

过

ฐँ

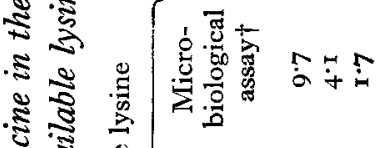

到

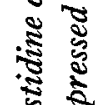

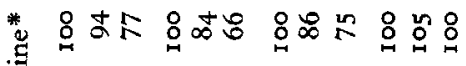

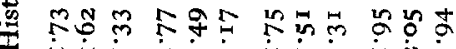

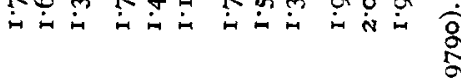

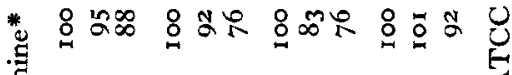

器

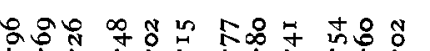

in in in in is in $\dot{+} \dot{+} \dot{0} \dot{b}$

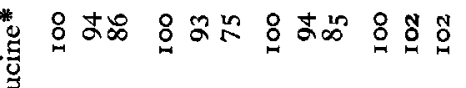

융 లై

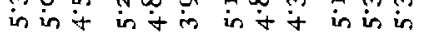

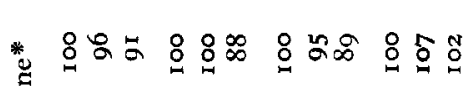

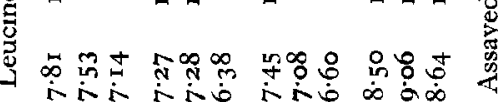

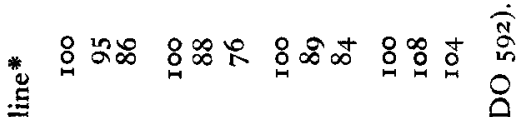

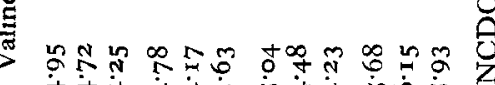

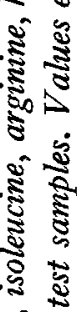

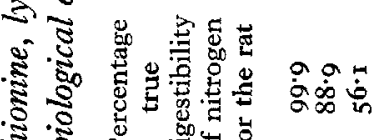

:

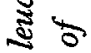

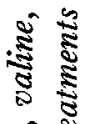

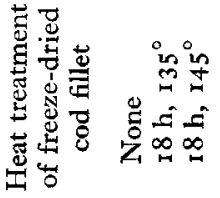

()

i.

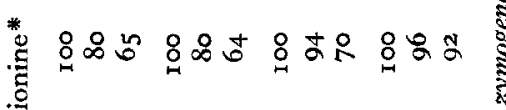

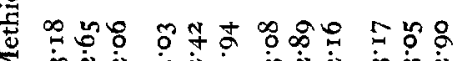

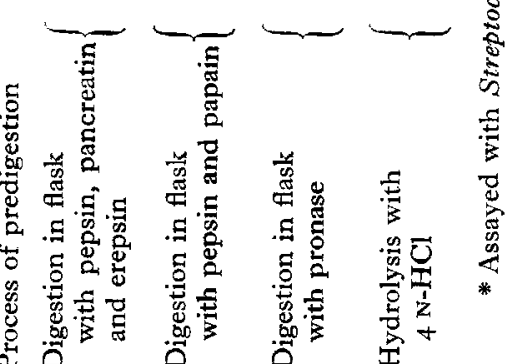

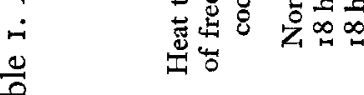

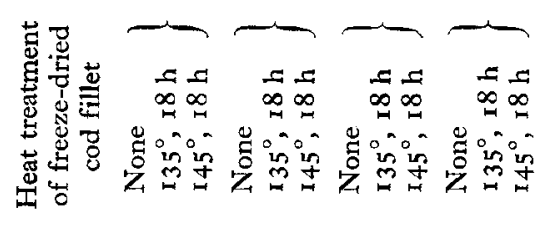


to have fallen to $22-36 \%$ of that in the unheated meal. Second in order of susceptibility to heat damage was methionine, of which about $66 \%$ was available in the more severely heated meal. Next came histidine, which was perhaps marginally less stable than were leucine, isoleucine, valine and arginine, which were comparatively stable to heating.

When these results are compared with those of the rat growth tests (Table I) it is clear that much more of the methionine, lysine and isoleucine in the severely heated meal was susceptible to enzymic release and utilized by the test micro-organisms than was biologically available to the rat. Thus, as percentages of the content in the unheated meal, about $66 \%$ of the methionine, about $82 \%$ of the isoleucine and about $28 \%$ of the lysine were recovered in the microbiological assays of the in vitro digests (Table 2), as against only 33,37 and $12 \%$ measured in the rat growth tests (Table I).

With increasing severity of the heat treatment of the meals the biological availabilities of these amino acids for the rat fell more sharply than did the digestibility of the $\mathrm{N}$, and unless we may suppose that the availabilities of some other amino acids were actually enhanced by the heat treatment, then it must be that the amino acids absorbed from the heated meals were relatively poorly retained by the rat. A similar situation is evident in the results of Bunyan \& Price (1960) who examined a series of whale-meat meals of similar amino acid composition but of widely different nutritive quality. They found in tests with rats that biological values and digestibilities were closely correlated. From the poorer meals, containing relatively low proportions of available amino acids as judged in chemical and microbiological tests, correspondingly low percentages of the absorbed $\mathrm{N}$ were retained by the rats (cf. Ford, 1964). Miller, Carpenter \& Milner (1965) studied chemical and nutritional changes in heated cod muscle, and similarly concluded that the damaging effects of heat, demonstrated in growth tests with rats, were by no means explained by the lower digestibilities of the test preparations.

Table 3 shows the effects of heating the freeze-dried cod fillet on the partition of twelve amino acids between the 'undigested residue', 'protein', 'peptide' and 'free amino acids' components of pepsin-pancreatin-erepsin digests. The recovery values are calculated as percentages, relative to the amino acid content of the digest of the control meal ( = roo).

After being digested for $5 \mathrm{~h}$ in Sephadex gel, more than $75 \%$ of the leucine, arginine and methionine in the unheated meal, and more than $56 \%$ of the isoleucine valine and histidine, were recovered as the free amino acids, as against $49 \%$ of the lysine and $40 \%$ of the glutamic acid. After more prolonged digestion in flasks, $90 \%$ or more of the leucine, histidine, arginine, methionine and tyrosine, $82-84 \%$ of the lysine, isoleucine and valine, $75 \%$ of the threonine, $63-65 \%$ of the glutamic acid and cystine, and $52 \%$ of the aspartic acid, were recovered as the free amino acids. Thus already in the unheated meal there were apparent differences in the rates at which different amino acids were released under these conditions of enzymic digestion. It is of interest at this stage to consider the corresponding findings for the pronase digests of the unheated meal (Table 4). Here again lysine, threonine, glutamic acid, cystine and aspartic acid were released comparatively more slowly, and the ordering of the 
Vol. 20

$\widetilde{3}$

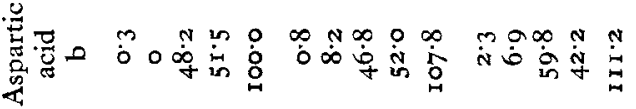

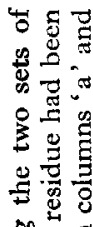

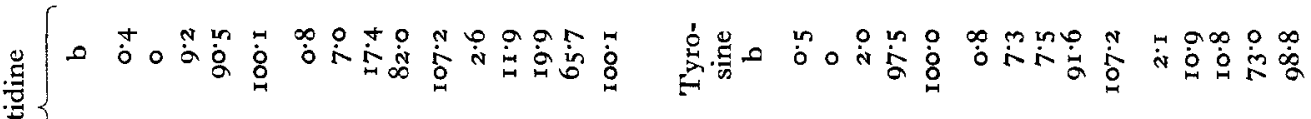

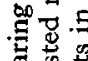

离

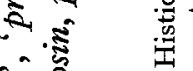

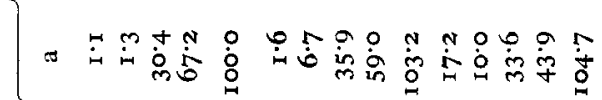

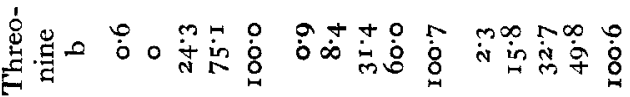

$\Xi$

ङ ฐ

s.

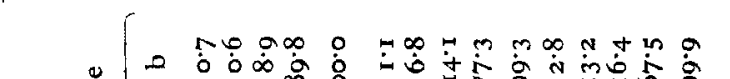

टँ

䒼

胥

递

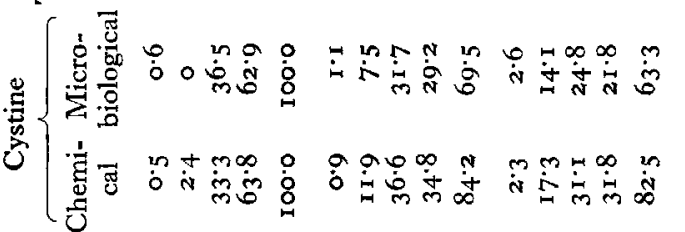

政

密:

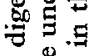

는

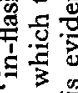

दे 용

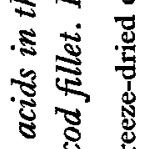

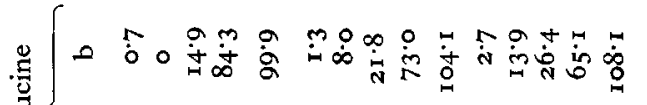

绨[0

赵

$\circ$.

离

宽

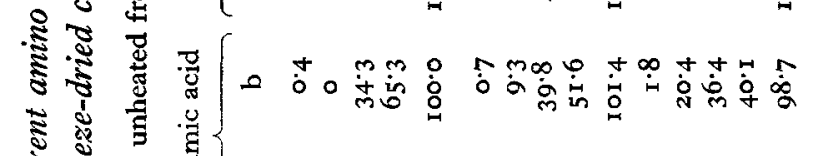

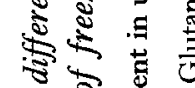

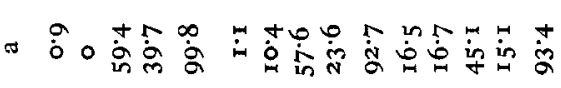

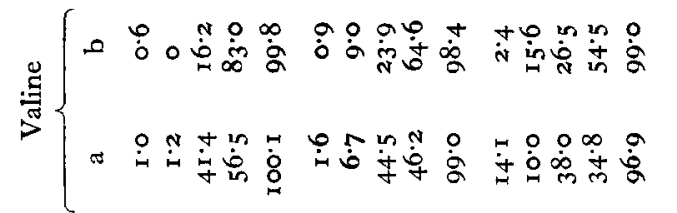

范获

药

$\Xi$.

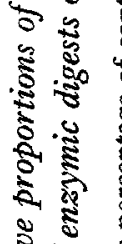

竎 के

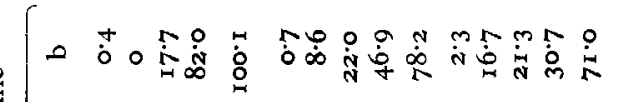

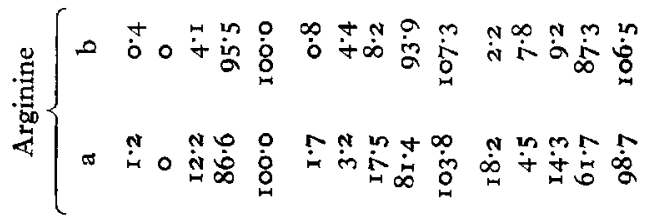

於.

5

5

Tु

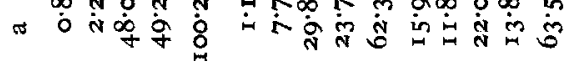

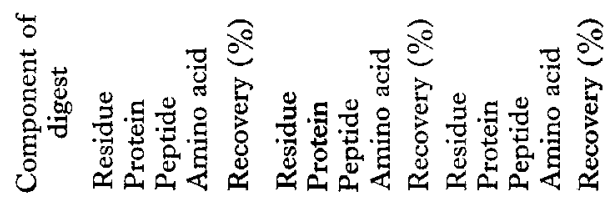

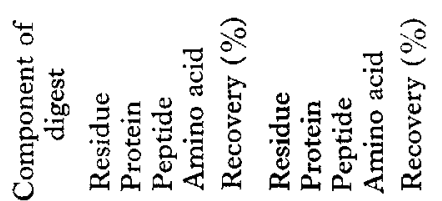

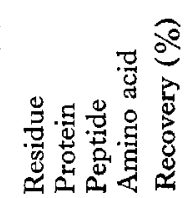

so

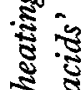

i.

胥

¿

$\dot{m}$
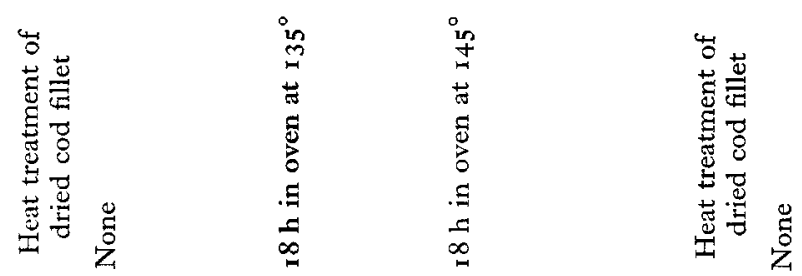

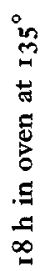

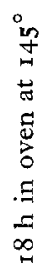

$\frac{2}{\frac{0}{0}}$ 


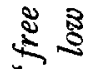

854 J. E. Ford AND D. N. SAlter

1966

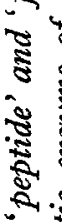

竞

$\sum^{2}$

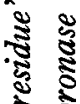

उั

क्ष

.

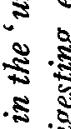

3

苍

.

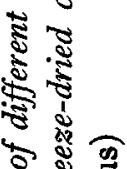

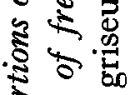

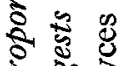

‥

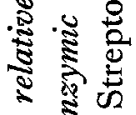

स

ธิ

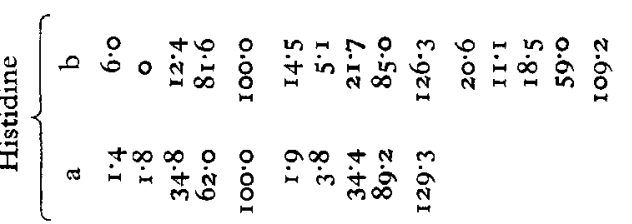

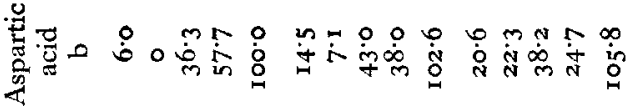

急过

$\pm$

递药

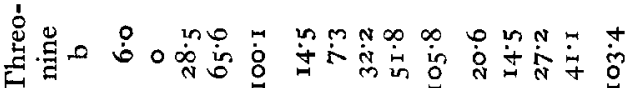

3 कo

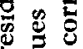

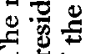

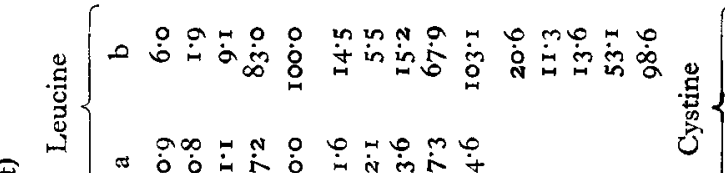

b

焉至

용

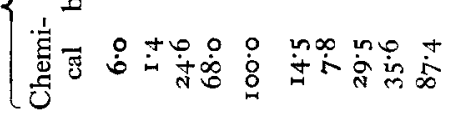

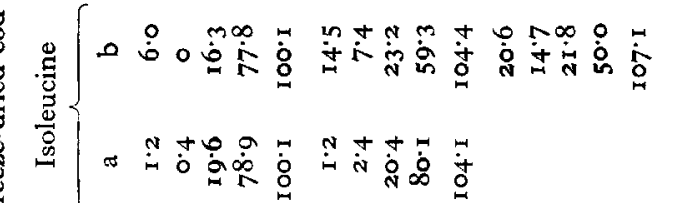

.

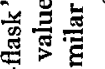

s.

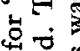

.

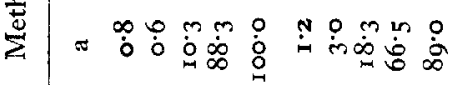

$\therefore$

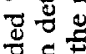

要娄

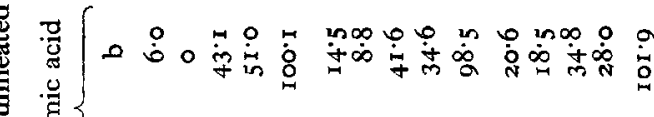

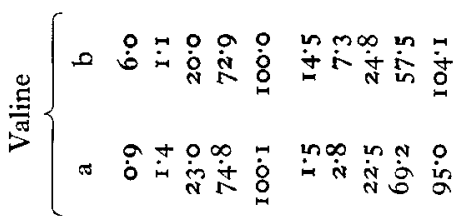

害密

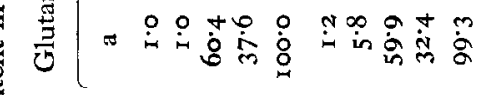

[ص

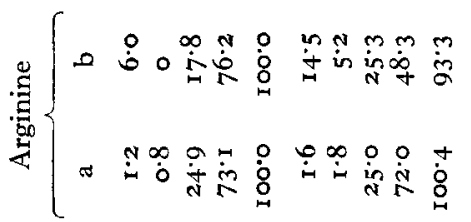

I 8

尊 营

a

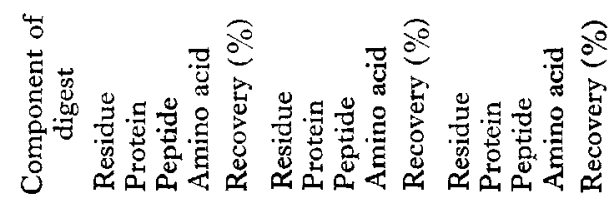

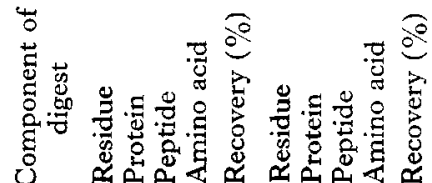

造

政

竞.

is

包

ํำ

J

So



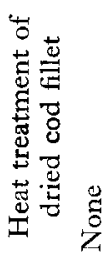

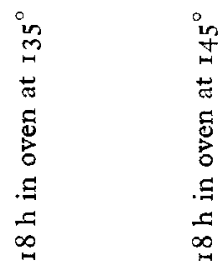

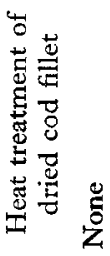

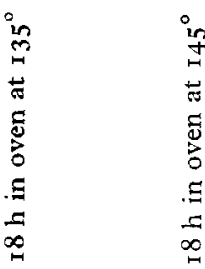

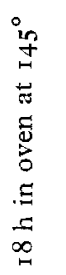

on

壳总

$8:$

哥焉

4

导氖苛

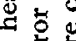

논

要 
extents of release of the different amino acids by the two enzyme systems was very much the same. Digestion of the unheated meal with pepsin and papain (Table 5) gave a lower yield of free amino acids in which again, however, the concentrations of lysine, glutamic acid and aspartic acid were relatively low. It is not clear to what extent this pattern of release of amino acids is characteristic of the fish meal, or reflects the specificities and peptidase activities of the digesting enzymes. It is conceivable that in the process of freeze drying and during subsequent storage in air, some of these more reactive amino acids might already have formed ester or amide bonds within the protein molecule, or reacted chemically with aldehyde groups produced during the oxidation of the small amount (c. I \%) of unsaturated fatty acids present in the meal, and so have become less easily accessible to proteolytic enzymes. Against this, there was no significant fall in the available lysine content of the meal, measured by reaction with dinitrofluorobenzene (Table I). Whatever the explanation, the slower in vitro release of lysine was not reflected in a reduced biological availability. The $\mathrm{N}$ in the unheated meal was wholly digestible, and the lysine was judged to be wholly available in the rat growth test.

Heating retarded the enzymic release of all the amino acids (Table 3 ). The free amino acids component of the digests decreased in amount and the peptide and protein increased. Analysis showed that the free amino acids in the digests of the heated meals were deficient in several amino acids relative to their content in the original unheated meal. Prolonged digestion, in flasks, of the more severely heated meal released only about $3 \mathrm{I} \%$ of the lysine and cystine, and of this 'free' cystine about one-third was not measured in the microbiological assay and was apparently inactive for the test microorganism. Part of the deficiency can be attributed to destruction of these amino acids. Only about $70 \%$ of the lysine and cystine was recovered in the digests of the severely heated meal.

As in the unheated meal, glutamic acid and aspartic acid were poorly digested, and only $40-42 \%$ appeared as free amino acids. About $50 \%$ of the methionine and threonine was released. As with cystine and lysine, part of the deficiency of methionine can probably be attributed to destruction during the heating. Valine $(55 \%)$, isoleucine $(65 \%)$, histidine $(66 \%)$, leucine $(68 \%)$, tyrosine $(73 \%)$ and arginine $(87 \%)$ were relatively more completely digested.

After digestion with pronase ('Table 4), in flasks, or with pepsin followed by pronase in Sephadex gel (Table 4) there were again marked differences in the extent of release of different amino acids. The general picture was broadly the same as for the pepsinpancreatin-erepsin digests and shows the relative incompleteness of the release of lysine, cystine, glutamic acid and aspartic acid, at least under these conditions of digestion in vitro.

Table 6 shows the relative concentrations of the twelve amino acids in the different components of the pepsin-pancreatin-erepsin digests. Prolonged digestion, in flasks, of the unheated meal yielded about $85 \%$ of the amino $\mathrm{N}$ as free amino acids (see p. 853 ); the amounts corresponded fairly closely to those in the original meal. With increasing severity of heating the yield of free amino acids in the digests declined, and the composition of the amino acid mixture changed markedly. The concentration of 
$\frac{8}{2}$ 氙

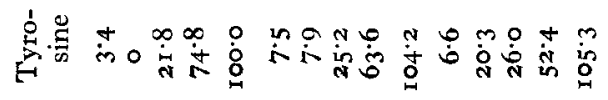

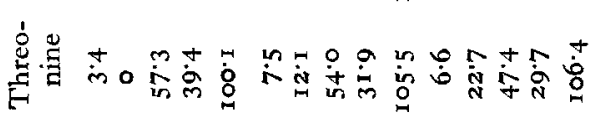

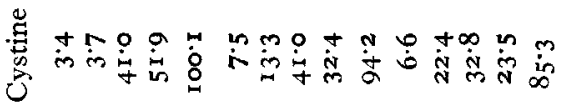

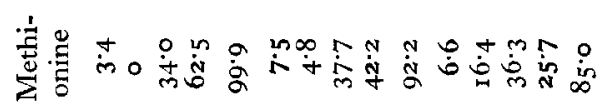

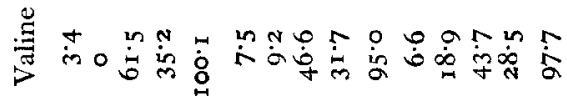

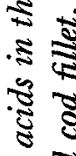

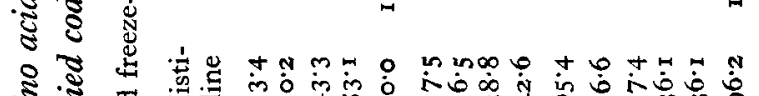

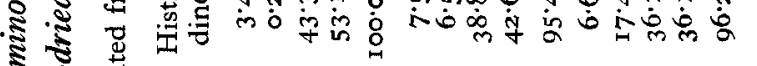

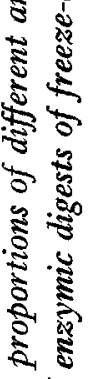
胥

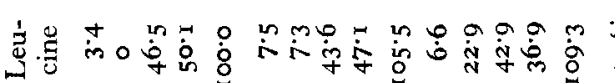
光 造

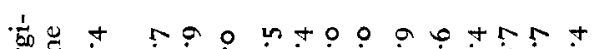

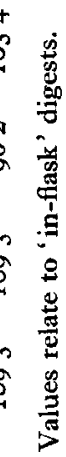

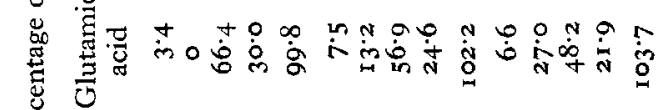

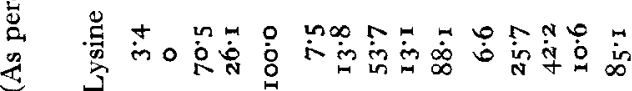

章

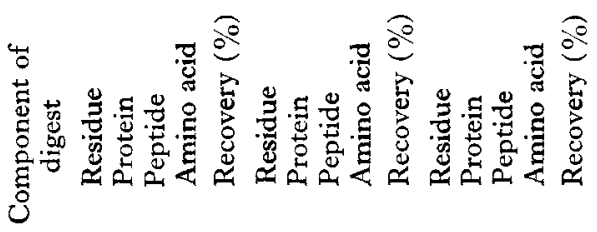

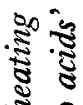

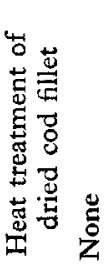

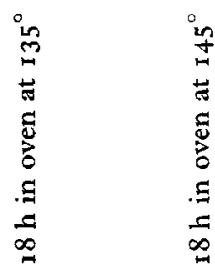

$\frac{1}{0}$ 
Vol. 20

竎 8

蕓.

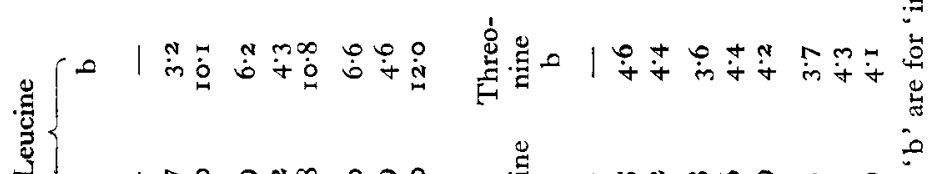

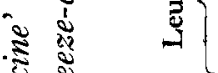

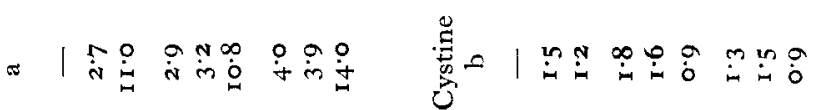

a

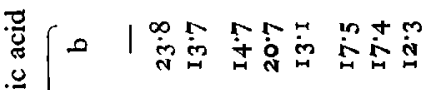

คิ

o

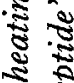

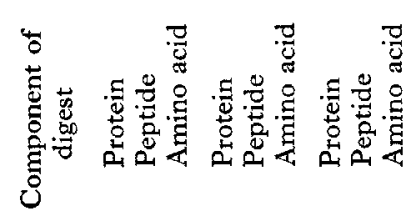

¿.

竎 5

है है है

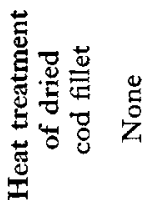

我 प ह ह

in

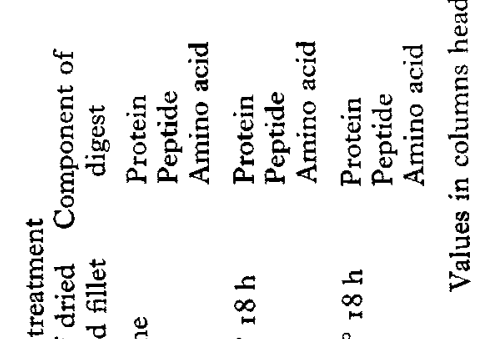


lysine fell sharply (from 10.4 to $5.8 \mathrm{~g} / \mathrm{ro0} \mathrm{g}$ leucine equivalent) as did that of methionine (from $3 \cdot 7$ to $2 \cdot 8$ ) and cystine (from $\mathrm{I} \cdot 2$ to 0.9 ). There were smaller falls in the concentrations of glutamic acid and threonine, and no significant change in the concentrations of histidine and valine. Isoleucine, leucine, arginine, tyrosine and aspartic acid increased in concentration.

After digestion for $5 \mathrm{~h}$ in Sephadex gel the free amino acid component again showed the marked fall with heating in the relative concentrations of lysine and methionine, and either no change or an upward trend in the concentrations of glutamic acid, isoleucine, leucine, histidine, arginine and valine.

The evidence presented here shows a marked differential effect of heating in retarding in vitro the enzymic release of several amino acids from the test protein, and identifies the rate and extent of release of lysine and the sulphur-containing amino acids as probably being critical in determining the biological value.

The results of feeding tests with rats showed corresponding differences in the proportions of lysine, methionine and isoleucine made unavailable by the heat treatment, though the values obtained for the heat-damaged meals (Table I) were all only about half those measured microbiologically after prolonged enzymic digestion in vitro (Table 2). It must be emphasized, however, that the term 'availability' is meaningful only when the particular system used for measuring it is carefully defined. In these rat tests the term implies the biological value of the test meal as the source of an individual amino acid, when included in a diet containing a basal protein deficient in that amino acid. Under these conditions of test, the rat growth response might be determined not only by the extent of the enzymic release of the amino acid from the test protein, but also by its rate of liberation relative to the rate of digestion of the basal protein. Analysis of intestinal contents of rats killed $2 \mathrm{~h}$ after a meal of these test proteins showed that heating had greatly retarded the course of digestion in vivo (Buraczewski, 1966).

Microbiological assays with Strep. zymogenes, carried out under arbitrarily standardized conditions, gave values for available methionine in a wide range of animal protein concentrates that were generally lower than the corresponding total values and correlated much better with results of chick assays (Miller, Carpenter, Morgan \& Boyne, 1965) and with rat NPU values (Ford, 1962). The microbiological assay values in Table $\mathbf{I}$, measured under the same standardized conditions, again corresponded broadly to the rat assay values and showed a loss of amino acids with heating, the extent of which was not at all evident in the 'total' values obtained after acid hydrolysis of the test meals (Table 2). But these 'available' values for the heated meals were not maximum values; after prolonged digestion with pepsin, pancreatin and erepsin the measured percentage availability of lysine in the more severely heated meal increased from $\mathbf{I} 8$ to 26 , of methionine from 53 to 65 , and of isoleucine from 65 to 86 . These values were now substantially higher than the availabilities measured with rats, and higher presumably than would have been found in similar growth tests with chicks. Even so, they may not even yet represent the ultimate availabilities. For lysine, this ultimate availability is perhaps best indicated by the DNFB-available lysine value of $3 \circ \mathrm{g} / \mathrm{r} 6 \mathrm{~g} \mathrm{~N}$, which should be compared with the value of $\mathrm{I} \cdot 3$ measured with 
rats and $2 \cdot 2$ measured microbiologically after prolonged digestion with pepsin, pancreatin and erepsin.

Miller, Carpenter \& Milner (1965) subjected freeze-dried cod fillets to sixteen different conditions of heat treatment and found, in tests with chicks and in microbiological assays with Strep. zymogenes, that the proportions of lysine and methionine made unavailable by the heat treatments were similar, and in further tests with Strep. zymogenes they found that methionine was no more affected than leucine. These findings seem altogether opposite to ours, though comparison is made difficult by the different conditions of heat treatment employed. We heated our freeze-dried cod fillet on open trays in an air oven, whereas Miller, Carpenter \& Milner (1965) heated their test samples in sealed cans or ampoules, at controlled moisture contents ranging between $\mathrm{r} \%$ and $50 \%$. The contradiction between our conclusions and those of Miller, Carpenter \& Milner ( 1965 ) could have arisen in part from the comparative lack of precision in the microbiological and biological tests, or from the differences in the methods of preparation of the test samples. Apart from the differences in moisture content there were probably differences also in content of reducing sugar, because Miller, Carpenter \& Milner (I965) steamed and pressed their cod fillets before freezedrying them. We must therefore be cautious about comparing the results.

Of the test preparations of Miller, Carpenter \& Milner (1965) the one most like ours had been heated for $24 \mathrm{~h}$ at $116^{\circ}$, at $14 \%$ moisture content. Its content of methionine available for Strep. zymogenes had fallen by $44 \%$, and for the chick by $3 \mathrm{I} \%$, of its original value. The corresponding percentage falls in available lysine were $33 \%$ measured chemically, and $48 \%$ measured with chicks. There is thus in these chick values of Miller, Carpenter \& Milner (1965) a suggestion of a greater loss of lysine $(48 \%)$ than of methionine $(3 \mathrm{I} \%)$ but the difference was presumably judged to be non-significant.

In an earlier investigation Ford (I965) found, as now, marked differences in the proportions of different amino acids made unavailable during heating in an air oven for $24 \mathrm{~h}$ at $140^{\circ}$. Lysine suffered considerably greater loss than methionine, which was more affected than leucine. Heating in pressure steam for $24 \mathrm{~h}$ at $12 \mathrm{I}^{\circ}$ caused a greater fall in in vitro enzymic digestibility but a smaller loss of available lysine. K. J. Carpenter (private communication) pointed out that these results seemed to indicate a distinct difference between the effects of wet and of dry heat-the conditions of dry heating causing relatively greater damage to the lysine than to the other amino acids. His interpretation takes into account only the chemically determined values for available lysine and discounts the lower values found by microbiological assays, which here again indicated a greater proportionate loss of lysine than of methionine.

Whatever the explanation of these different findings, the general question of the differential in the rates of release in vivo of amino acids from food proteins is of great theoretical and practical interest and needs further study.

We are grateful to Dr Lucyna Buraczewska for her contribution to this work and especially for the chemical analyses for cystine. We thank our colleague Dr J. W. G. Porter for his helpful interest, and Mr K. J. Scott for skilled technical assistance. 


\section{REFERENCES}

Andrews, P. (1964). Biochem. 7. 9r, 222.

Barton-Wright, E. C. (1963). Practical Methods for the Microbiological Assay of the Vitamin B Complex and Amino Acids. London: United Trade Press Ltd.

Bunyan, J. \& Price, S. A. (1960). F. Sci. Fd Agric. Ir, 25.

Buraczewski, S. (I966). Factors affecting amino acids in the blood. PhD Thesis, University of Reading. Carpenter, K. J. (1 960). Biochem. F. 77, 604.

Ford, J. E. (1960). Br. F. Nutr. 14, 485 .

Ford, J. E. (1962). Br. F. Nutr. 16, 409.

Ford, J. E. (I964). Br. Y. Nutr. r8, 449.

Ford, J. E. (1965). Br. F. Nutr. r9, 277.

Kennedy, T.S. (1965). F. Sci. Fd Agric. 16, 433.

Mauron, J., Mottu, F., Bujard, E. \& Egli, R. H. (1955). Archs Biochem. Biophys. 59, 433.

Melnick, D., Oser, B. L. \& Weiss, S. (I946). Science, N. Y. 103, 326.

Miller, E. L., Carpenter, K. J. \& Milner, C. K. (1965). Br. F. Nutr. 19, 547.

Miller, E. L. \& Carpenter, K. J., Morgan, C. B. \& Boyne, A. W. (r965). Br. F. Nutr. I9, 249.

Moore, S. (1963). F. biol. Chem. 238, 235.

Moore, S. \& Stein, W. H. (1954). F. biol. Chem. 2 rI, 907.

Nasset, E. S. (1956). In Some Aspects of Amino Acid Supplementation, p. 3. [W. H. Colc, editor.] New Brunswick, N.J.: Rutgers University Press.

Nomoto, M., Narahashi, Y. \& Murakami, M. (ı 96o). F. Biochem., Tokyo 48, 593. 